\title{
Survey the Main Factor Impact on Work Motivation
}

\author{
Freyedon Ahmadi \\ Public management Department, Payame Noor university, 19395-3697 Tehran, I.R. of IRAN \\ Accepted: December 2, 2011 Published: January 9, 2012 \\ Doi:10.5296/ijld.v2i1.1254ＵRL: http://dx.doi.org/10.5296/ijld.v2i1.1254
}

\begin{abstract}
The aim of this paper is determining factors which they have impact on work motivation. In current study we examine the effect of individual attributes, job characteristics, and organizational variables on three aspects of work motivation: job satisfaction, organizational commitment, and job involvement. The results indicated that managers have varying degrees of influence over these different aspects of work motivation, with greatest influence over job satisfaction and least influence over job involvement.
\end{abstract}

Key words: Job Satisfaction, Organizational Commitment, Job Involvement, Work Motivation

\section{Introduction}

This article examines the ways in which public managers can influence different aspects of work motivation. Herbert Simon suggested that the basic challenge for all organizations is "inducing their employees to work toward organizational goals" (Simon 1997, p.276). More recently, Pfeffer (1998) has argued that the key to long-term success has been, and will continue to be, how organizations manage their employees, since creating meaningful work and otherwise keeping employees happy is central to fostering organizational effectiveness. But how do organizations know if they are keeping employees happy, motivated, and actively committed to the organization? There is no simple answer, because what we refer to as work motivation is a multidimensional concept linked to how employees interact with and views their organizations, and is reflected in the degree to which the employee feels a sense of connection, obligation, and reward in working for the organization (Allen \& Meyer 1990).

Locke and Latham's definition reflects the broad scope of work motivation: "The concept of motivation refers to internal factors that impel action and to external factors that can act as inducements to action" (2004, p.388). In operational zing work motivation we do not reinvent the wheel, but instead employ three previously established concepts as dependent variables: job satisfaction, organizational commitment, and job involvement. Locke's (1997) review of the theories and associated empirical work on work motivation places these as central and interrelated components in explaining or representing the concept of work motivation. Job 
satisfaction has been defined as the "pleasurable or positive emotional state resulting from the appraisal of one's job or job experience" (Locke, 1976, p.1300). Employee commitment indicates the sense of loyalty and obligation the employee holds toward the organization (Allen \& Meyer 1990). Organizational commitment helps to motivate individuals to pursue collective goals rather than individual outcomes (Ellemers, de Gilder \& Van den Heuvel, 1999). Job involvement indicates the degree to which the workplace contributes to one's self image (Lodahl \& Kejner, 1965) and satisfies important needs (Dubin, 1956; 1968).

Consistent with Locke and Latham, we conceptualize motivation broadly, to incorporate factors that make the employee more committed to the organization. This point is important because some research in organization behavior categorizes the motivation more narrowly, and has noted that such motivation does not necessarily overlap with job satisfaction. However, job satisfaction is a critical predictor of turnover and absenteeism, and so our construction of motivation is broader than the arousal of effort, but also includes factors relating to the motivation to come to work and engagement with the work environment.

Recent work from Harrison, Newman and Roth (2006) supports this perspective, arguing that variables such as job satisfaction and organizational commitment overlap a good deal and could be collectively considered when examining employee attitudes and behavior. Rather than describing their approach in terms of motivation, they describe an "attitude-engagement" model, arguing that "when attempting to understand patterns of work behavior from attitudes such as job satisfaction and organizational commitment, researchers should conceptualize the criterion at a high level of abstraction." (Harrison et al. 2006, p. 316, italics in original). Harrison et al. point to the importance of such attitudes to outcome measures such as lateness, absenteeism, turnover and some aspects of performance.

\section{Review of research literature}

The personnel literature on employee motivation, commitment, and job satisfaction suggests that employee attitudes are essentially driven by both individual attributes and work context. A model of work motivation, therefore, seems relatively straightforward, implying the need to account for the relevant individual and work environment variables.

One area of complexity is in modeling the effect of the organization on work motivation. In recent years Wright and colleagues (Wright, 2001, 2003; Wright \& Davis, 2002; Kim \& Wright, 2004) have developed exemplary models of employee motivation, job satisfaction, and work alienation. This work is most valuable in mapping distinctions and interrelationships between different organizational variables. For a start, Wright distinguishes between job characteristics and organizational characteristics. "Job characteristics describe aspects of the job or task an employee performs, while work context pertains to characteristics of the organizational setting (e.g., the organization's reward systems, goals, or degree of formalization) in which the employee must perform work" (Wright, 2001, p.562). Wright's work also identifies organizational factors as exerting an influence on employee attitudes indirectly via job characteristics. For example, organizational level conflict and goal clarity will in turn foster job level conflict and role clarity respectively. Our theory also makes room for organizational factors having a direct effect on employee attitudes, building 
on the work of Ting (1997) in the area of job satisfaction.

In the area of work motivation, we expect that organizations will have greatest influence over job satisfaction, less influence over employee commitment, and the least influence over employee involvement. The motivation for our hypothesis is based on the nature of the type of work motivation, which in turn shapes which workable levers are useful. For some types of work motivation, managers have a relatively good understanding of how to affect the particular aspect of motivation and access to appropriate workable levers. We expect organizations to have the greatest influence over job satisfaction, in part because job satisfaction might be "the most intensively studied variable in organizational research" (Rainey, 1997, 244), meaning that the antecedents of this concept are well understood.

We expect that job involvement will be primarily shaped by individual attributes and previous life experiences rather than by workable levers. We examine these individual attributes, job characteristics, and organizational level variables in greater detail in the following sections.

H1: Organizations will have greatest influence over job satisfaction, less influence over employee commitment, and the least influence over job involvement.

\section{Individual Attributes}

The first source of antecedents for work motivation comes from the employee's individual attributes. Individual attributes are what an employee brings to the organization, and consists of characteristics such as demographic characteristics or predispositions that are difficult or impossible to change. The critical levers managers have to shape the individual characteristics of their employees are recruitment, selection, hiring, promotion and firing; although such levers are constrained by rules that seek to avoid unfair treatment.

We expect that the employee's age, background, and beliefs will have some impact on whether an employee is engaged in the workplace or not. The literature on motivation points out that an individual's beliefs about what is important in life, and in their job, can be characterized in terms of intrinsic and extrinsic motivations. Intrinsic motivators in public organizations are somewhat distinct from the private sector, because of the issue of context and evidence that public employees are motivated by doing public work (Rainey, 1982; Wittmer, 1991). An intrinsic motivator reflective of public sector work, therefore, would be Public Service Motivation (PSM): “an individual's predisposition to respond to motives grounded primarily or uniquely in public institutions and organizations" (Perry and Wise, 1990, p.68).

H2: Employees with high levels of PSM will have higher levels of work motivation.

\section{Job Characteristics}

Job characteristics are aspects of the individual employee's job and tasks which shape how the individual perceives their particular role in the organization. Goal theory suggests that goals that are both specific and difficult to achieve lead to higher performance than goals that tend to be easy or ambiguous (Locke \& Latham, 1990). Role clarity provides a sense of purpose and increases the individual's belief that the goal is achievable. Ting (1997) finds 
that clarity of tasks leads to greater job satisfaction. We expect that greater role clarity will create employees who are more satisfied with, committed to, and involved in their work.

H3: Employees with clear roles will have higher levels of work motivation.

\section{Organizational Factors}

While organizational factors may shape employee jobs and tasks in specific ways, we also propose that employee perceptions about organizational culture, purpose, achievement, and progress will influence their sense of whether the organization is a rewarding place to work and deserves their active engagement. In considering organizational factors, we sought to exclude factors that plausibly have, or have been shown to have, indirect effects on work motivation via work characteristics, such as organizational resources, procedural constraints, or organizational goal clarity.

Instead we focus on what Barnard (1938) referred to as "methods of persuasion": ways in which managers seek to shape the employee-held views of the organization. Perhaps the most potent way in which this occurs is through organizational culture. A basic purpose of an organizational culture is to foster internal integration and to differentiate the organization and its members from the outside world (Schein, 1996). Culture, like work motivation itself, is a multidimensional concept (Quinn \& Rohrbaugh, 1984). Zammuto \& Krakower (1991) operationalize organizational culture as being comprised of four distinct dimensions. One of these dimensions stands out as being likely to foster high levels of work motivation. Group cultures are associated with a focus on people rather than the organization, flexibility rather than control. Group cultures are also characterized by an emphasis on employee cohesion and morale. When employees believe that their organization is a closely-knit team, this creates a sense of mutual expectation and commitment. Ouchi (1981) referred to this as a "clan culture" (see also Ban, 1995). Kaufman's (1967) classic study of forest rangers had already illustrated how clan-like cultures could foster and reinforce a sense of shared commitment among employees. Kaufman built on insights first developed by the Hawthorne experiments - that employees consider themselves as part of a social network. Group norms are powerful shapers of individual attitudes and actions. Empirical support comes from Khojasteh (1993) and Ting (1997), who find that interpersonal relations are important to job satisfaction, and Kim (2002), who finds that more inclusive and participatory styles of management also foster increased job satisfaction.

Ellickson (2002) also finds that the sense of esprit de corps or departmental pride was the most influential predictor of job satisfaction in his sample of municipal employees, while Steijn (2004) finds that organizational climate was important in predicting job satisfaction.

H4: Employees who experience a strong group culture will have higher levels of work motivation.

\section{Methodology}

In terms of the practical objective and the data collection method, the present research is descriptive and in terms of the relation between the variables it is of the Casual type. The 
method of conducting the research is 'Survey research" and the foremost advantage of it is possibility of generalizing the results. 270 people of custom organization in iran were selected as sample

\section{Finding}

Table 1 and table 2 indicated Correlation Matrix and Descriptive Statistics

Table 1. Correlation Matrix

\begin{tabular}{|c|c|c|c|c|c|c|c|c|c|c|}
\hline & 1 & 2 & 3 & 4 & 5 & 6 & 7 & 8 & 9 & 10 \\
\hline 1. Job satisfaction & 1 & & & & & & & & & \\
\hline $\begin{array}{l}\text { 2. Organizational } \\
\text { commitment }\end{array}$ & 0.519 & 1 & & & & & & & & \\
\hline 3. Job involvement & 0.427 & 0.417 & 1 & & & & & & & \\
\hline $\begin{array}{l}\text { 4. Public Service } \\
\text { Motivation } \\
\text { Attraction } \\
\text { to Policymaking) }\end{array}$ & 0.218 & 0.314 & 0.314 & 1 & & & & & & \\
\hline $\begin{array}{l}5 . \quad \text { Importance of } \\
\text { advancement } \\
\text { opportunity }\end{array}$ & 0.101 & 0.201 & 0.098 & 0.11 & 1 & & & & & \\
\hline 6. Self efficacy & 0.207 & 0.124 & 0.135 & 0.198 & 0.201 & 1 & & & & \\
\hline 7. Role clarity & 0.147 & 0.241 & 0.134 & 0.174 & 0.157 & 0.134 & 1 & & & \\
\hline 8. Job routineness & -0.124 & -0.107 & -.205 & -0.14 & -0.8 & -0.12 & -0.24 & 1 & & \\
\hline 9. Group culture & 0.147 & 0.247 & 0.214 & 0.124 & 0.132 & 0.241 & 0.124 & 0.12 & 1 & \\
\hline $\begin{array}{l}\text { 10.Sense of } \\
\text { organizational purpose }\end{array}$ & 0.07 & 0.12 & 0.147 & 0.098 & 0.074 & 0.114 & 0.011 & 0.014 & 0124 & 1 \\
\hline
\end{tabular}

Table 2. Descriptive Statistics

\begin{tabular}{|l|l|l|l|}
\hline Variables & $\begin{array}{l}\text { Potential } \\
\text { Scale Range }\end{array}$ & mean & $\begin{array}{l}\text { Standard } \\
\text { Deviation }\end{array}$ \\
\hline Job satisfaction & $3-15$ & 13.02 & 2.09 \\
\hline Organizational commitment & $3 .-21$ & 15.1 & 3.82 \\
\hline Job involvement & $3 .-15$ & 11.9 & 3.98 \\
\hline $\begin{array}{l}\text { Public Service Motivation (Attraction } \\
\text { to Policymaking) }\end{array}$ & $3 .-21$ & 17.6 & 2.74 \\
\hline Importance of advancement opportunity & & & \\
\hline Self efficacy & $1-5$ & 3.5 & 1.1 \\
\hline Role clarity & $1-5$ & 3.24 & 1.17 \\
\hline Job routineness & $3 .-15$ & 8.1 & 2.31 \\
\hline Group culture & $1-4$ & 2.79 & 0.17 \\
\hline Sense of organizational purpose & $3-15$ & 6.87 & 1.12 \\
\hline
\end{tabular}


Table 3: Results of OLS Regression on Work Motivation

\begin{tabular}{|c|c|c|c|}
\hline Variable & $\begin{array}{l}\text { Job } \\
\text { satisfaction }\end{array}$ & $\begin{array}{l}\text { Organizational } \\
\text { commitment }\end{array}$ & $\begin{array}{l}\text { Job } \\
\text { involvement }\end{array}$ \\
\hline \multicolumn{4}{|l|}{ Individual Attributes } \\
\hline Public Service Motivation (Attraction to Policymaking & $.050+$ & $.177 * *$ & $.174 *$ \\
\hline Importance of advancement opportunity & $.174 *$ & $.367 * *$ & $.738^{* * *}$ \\
\hline \multicolumn{4}{|l|}{ Job Characteristics } \\
\hline Role clarity & $.316^{* * *}$ & $.250 * *$ & .091 \\
\hline Job routineness & $-.337 * *$ & -.099 & -.064 \\
\hline \multicolumn{4}{|l|}{ Organizational Characteristics } \\
\hline Group culture & $.407 * *$ & $1.675 * * *$ & $.551^{*}$ \\
\hline Sense of organizational purpose & $.128 * *$ & $.178^{*}$ & .039 \\
\hline Model F-Value & 18.362 & 13.251 & 3.77 \\
\hline $\mathrm{N}$ & 256 & 258 & 257 \\
\hline $\mathrm{R}$ & .654 & .590 & .364 \\
\hline Adjusted R2 & 0.427 & .348 & 0.97 \\
\hline \multicolumn{4}{|c|}{$\begin{array}{l}\text { Standardized beta coefficients displayed in the table } \\
* * * \text { statistically significant at } .001, * * \text { statistically significant at } .01, \\
\text { *statistically significant at } .05,+ \text { statistically significant at } .1 \\
\text { Note that significance levels are one-tailed tests if matching a predicted direction, two-tailed } \\
\text { Tests otherwise. }\end{array}$} \\
\hline
\end{tabular}

Before we examine the impact of individual variables, it is worth assessing the degree of support for our macro-hypothesis that a seemingly simple concept such as work motivation has different aspects and that managers have varying degrees of influence over what shapes each of these aspects. While our model can be improved further, the results appear to offer support for this proposition. A glance at the three models indicate that our models fare well at explaining job satisfaction (adjusted R2 of .410), moderately well at explaining organizational commitment (adjusted R2 of .329), but relatively poorly at explaining job involvement (adjusted R2 of .107). More to the point, the source of the explanatory power of each model varies in ways that are consistent with our hypothesis. A simple but effective illustration of this point is to compare the nature of the significant variables for each model. For job satisfaction, only two of the seven significant variables come from individual attributes, the rest are the result of either job or organizational characteristics, categories over which senior managers can exert at least some degree of influence. For organizational commitment, two of five significant factors are individual attributes. For job involvement, four of six significant variables are individual attributes.

The results of the PSM variable are also illustrative of our premise, and provide further 
evidence of the importance of PSM in the public sector. Job satisfaction, which is based largely on the benefits that employees perceive they are receiving from their organization, is positively related with PSM. This is consistent with the findings of Naff and Crum (1999), although our findings employ one subscale of PSM related to attraction to policy-making and rely on a much smaller sample than Naff and Crum. PSM also shapes organizational commitment and involvement. Our measure of extrinsic motivation - advancement opportunities - is significantly and positively related to job satisfaction. Across the three models we find that public employees who place high value on advancement opportunities tend to be more engaged. The nature of the data does not tell us whether this is because such individuals tend to commit more to their work in the hopes of achieving such promotions, or whether public organizations have been successful at satisfying this desire for promotion.

Another possible explanation for this result in conjunction with the negative effect of organizational tenure on job involvement is that certain aspects of the work environment in the public sector, at least in the sample we study, have a negative effect on work motivation. Over time, such aspects of the work environment not only reduce job involvement but also impede self efficacy and associated commitment to one's work role from generalizing to a higher level such as the organization.

Thus, a highly trained professional in public service would tend to identify and express high commitment with the profession rather than the organization (Mosher 1982).

The findings on job characteristics underline the limited workable levers that managers can use to shape work involvement. Neither job routineness or role clarity, or even self-efficacy, is a significant predictor of work involvement. Job routineness is also a negative and significant predictor of job satisfaction, confirming previous findings (Wright \& Davis 2002). Role clarity is a positive and significant predictor of both job satisfaction and organizational commitment.

One frequently cited characteristic of the public sector is the potential for ambiguity or outright conflict between competing goals (Chun \& Rainey, 2005; Pandey \& Rainey 2006; Rainey, Backoff \& Levine, 1976; Rainey, 1993). Organizations with clear goals and a clear understanding of those goals are generally expected to be more effective (Wilson, 1989).

Organizational goal clarity in turn leads to clearer supervisory feedback and clarity in specific tasks faced by an individual employee (Wright, 2003). Such clarity also positively affects employee attitudes, and our results support similar findings on job satisfaction (Wright \& Davis, 2002) and work motivation (Wright, 2003).

This article also sought to make a contribution by arguing that managers could influence work motivation by changing the employees' perception of the organization. While the organizational level variables are not uniformly significant across all measures of work motivation, enough of them are significant to provide support for this claim. Group culture is positively and significantly associated with job satisfaction, organizational commitment, and job involvement. Our respondents who perceived a shared culture of mutual commitment and a family-like atmosphere felt a higher sense of loyalty to their organization and found work more satisfying. A sense of organizational purpose was also important for job satisfaction and organizational commitment. Taken together, the influence of group culture and sense of purpose suggests that creating a work environment where employees are satisfied means 
more than satisfying extrinsic motivators and offering accommodating job characteristics. Job satisfaction is similar to other aspects of work motivation in that it can be nurtured by fostering a sense of belonging and shared achievement in a hospitable social network.

\section{References}

Ban, C. (1995). How Do Public Managers Manage? Bureaucratic Constraints, Organizational Culture and the Potential for Reform. San Francisco: Jossey-Bass.

Boles, J.S. \& Babin, B.J. (1994). Role stress revisited: One or two constructs? Journal of Marketing - Theory and Practice, 2, 57-69.

Bozeman, B. (2000) Bureaucracy and Red Tape. Upper Saddle River, NJ: Prentice Hall.

Carson, Kerry D. \& Carson, P.P. (1997). Career Entrenchment: A Quiet March Toward Occupational Death. The Academy of Management Executive, 11(1): 62-75

Chun, Y.H. \& Rainey, H.G. (2005). Goal ambiguity in U.S. federal agencies. Journal of Public Administration Research and Theory, 15(1), 1-30.

Cohen, A. (2003). Multiple Commitments in the Workplace: An Integrative Approach. Mahwah, NJ: Lawrence Erlbaum Associates, Publishers.

Daniels, M.R. (1998). Medicaid reform and the American states: Case studies on the politics of managed care. Westport, CT: Auburn House.

Dillman, D. A. (2000). Mail and Internet Surveys: The Tailored Design Method. 2nd ed., New York: John Wiley

Ellickson, M. C. (2002). Determinants of job satisfaction of municipal government employees. Public Personnel Management, 31(3), 343-358.

Grogan, C., and Patashnik, E. (2003). Between welfare medicine and mainstream entitlement: Medicaid at the political crossroads. Journal of Health Politics, Policy and Law, 28(5): 822-858.

Harrison, D.A., Newman, D.A., Roth, P.L. (2006). How Important are Job Attitudes? MetaAnalytic Comparisons of Integrative Behavioral Outcomes and Time Sequences. Academy of Management Journal, 49(2): 305-325.

Herzberg, F. (1966). Work and the Nature of Man. Cleveland: World.

Ingraham, P.W., Selden, S.C. \& Moynihan, D.P. (2000). People and Performance: Challenges for the Future Public Service-the Report from the Wye River Conference. Public Administration Review, 60(1), 54-60.

Kim, S. (2002). Participative Management and Job Satisfaction: Lessons for Management Leadership. Public Administration Review, 62(2), 231-241.

Kim, S. \& Wright, B.E. (2004). IT Employee Work Exhaustion: Toward an Integrated Model of Antecedents and Consequences. Paper presented at the annual meeting of the Academy of Management, August 8-11, 2004, New Orleans.

Klingner, D.E. and Nalbandian, J. (2003). Public Personnel Management: Contexts and Strategies, 5th Edition. Upper Saddle River, NJ: Prentice Hall.

Locke, E.A. \& Latham, G.P. (2004). What should we do about motivation theory? Six recommendations for the twenty-first century. Academy of Management Review, 29(3), 388-403.

Moynihan, D.P. \& Pandey, S.K. (2007). The Role of Organizations in Fostering Public 
Service Motivation. Public Administration Review 67(1): 40-53.

Pandey, S.K. (2002). Assessing state efforts to meet baby boomers' long-term care needs: A case study in compensatory federalism. Journal of Aging and Social Policy, 14(3/4): 161-179. Pandey, S.K., and Garnett, J.L. (2006). Exploring public sector communication performance: Testing a model and drawing implications. Public Administration Review, 66(1): 37-51.

Pandey, S.K. and Rainey, H.G. (2006). Public Managers' Perceptions of Organizational Goal Ambiguity: Analyzing Alternative Models. International Public Management Journal, 9(2): 85-112.

Pandey, S.K., and Kingsley, G.A. (2000). Examining red tape in public private organizations: Alternative explanations from a social psychological model. Journal of Public Administration Research and Theory, 10(4): 779-99.

Rainey, H.G. (1993). A Theory of Goal Ambiguity in Public Organizations. In J.L. Perry (Ed.) Research in Public Administration, 2, 121-166.

Schein, E. (1996). Culture: The Missing Variable in Organizational Studies. Administrative Science Quarterly, 41(2), 229-241.

Selden, S.C. \& Moynihan, D.P. (2000). A Model of Voluntary Turnover in State Government. Review of Public Personal Administration, 20(2): 63-75.

Simon, Herbert. (1997). Administrative Behavior: A Study of Decision-Making Processes in Administrative Organizations, 5th edition. New York, NY: Macmillian Company.

Smith, V., Ramesh, R., Gifford, K., Ellis, K., Rudowitz, R., and O’Malley, M. (2004). The continuing medicaid budget challenge: State medicaid spending growth and cost containment in fiscal years 2004 and 2005. Results from a 50-state survey. Washington, D.C.: The Kaiser Commission on Medicaid and the Uninsured, Publication No. 7190.

Steijn, B. (2004). Human Resource Management and Job Satisfaction in the Dutch Public Sector. Review of Public Personnel Administration, 24(4), 291-303.

Thompson, F.J., and Dilulio, J.J. Jr. (1998). Medicaid and devolution: A view from the states. Washington, DC: Brookings Institution Press.

Traut, C.A., Larsen, R. \& Femier, S.H. (2000). Hanging On or Fading Out: Job Satisfaction and the Long-Term Worker. Public Personnel Management, 29(3): 343-352.

Vigoda, E. (2000). Organizational Politics, Job Attitudes, and Work Outcomes:

Exploration and Implications for the Public Sector. Journal of Vocational Behavior, 57, 326-347.

Wiener, Y. (1982). Commitment in Organizations: A Normative View. Academy of Management Review 7(3): 418-28.

Wilson, J.Q. (1989). Bureaucracy: What Government Agencies Do and Why They Do It. New York, NY: Basic Books, Inc.

Wittmer, D. (1991). Serving the People or Serving for Pay: Reward Preferences Among Government, Hybrid Sector, and Business Managers. Public Productivity and Management Review 14(4), 369-83.

Wright, B.E. (2001). Public Sector Work Motivation: Review of Current Literature and a Revised Conceptual Model. Journal of Public Administration and Theory, 11(4), 559-586.

Wright, B.E. \& Davis, B.S. (2002). Job Satisfaction in the Public Sector: The Role of the Work Environment. American Review of Public Administration, 33(1), 70-90. 
Zammuto, R.F. \& Krakower, J.Y. (1991). Quantitative and Qualitative Studies of Organizational Culture. Research in Organizational Change and Development 5, 83-114. 